\title{
Novel approach for SVPWM of two-level inverter fed induction motor drive
}

\author{
Olwi A. Elkholi ${ }^{1}$, Mohamed A. Enany ${ }^{2}$, Ahmed F. Abdo ${ }^{3}$, Mahmoud Eid ${ }^{4}$ \\ ${ }_{1,3}$ Electrical Engineering Department, Faculty of Engineering, Menofeya University, Egypt \\ ${ }^{2,4}$ Electrical Power \& Machines Department, Faculty of Engineering, Zagazig University, Egypt
}

\begin{tabular}{l}
\hline Article Info \\
\hline Article history: \\
Received Apr 1, 2019 \\
Revised Jul 8, 2019 \\
Accepted Jul 20, 2020 \\
\hline
\end{tabular}

Keywords:

Two - level inverter Induction motor drive Space vector pulse width Modulation MATLAB/Simulink

\begin{abstract}
Due to their better DC bus utilization and easier digital realization, Space Vector Pulse Width Modulation (SVPWM) scheme is the most widely used PWM scheme. Also, two-level inverter is the traditional frequency converter because it has fewer components and is lower complex to control, but on the other hand, it generates higher harmonic distortion. This paper presents the realization of novel SVPWM approaches applied to the three-phase induction motor drives. Specifically, various schemes are based on using more combinations of step operation in each cycle to approximate the reference vector, such as 24 and 48 step operations in each cycle. The basic principle of conventional SVPWM with different modulation index $M$ is presented. The switching sequences of new approaches are described. The modulation signals waveforms, DC bus voltage utilization, De-rated motor torque, standard error of average torque, voltage and current harmonics of new approaches are analyzed by the MATLAB/Simulink software. The results confirm that 48 step SVPWM approach is the best compared to other approaches.
\end{abstract}

This is an open access article under the CC BY-SA license.

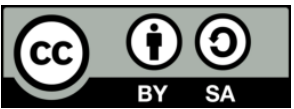

\section{Corresponding Author:}

Mahmoud Eid,

Department of Electrical Power \& Machines Engineering,

Zagazig University, Egypt.

Email: meid64520@gmail.com

\section{INTRODUCTION}

Induction motor drives are used in industries sectors due to its self-starting and constant speed features. Multilevel inverters are used to control the induction motor speed. Because of acceptable harmonics levels and their control flexibility, PWM voltage source inverters are used. For better performance, different modulation techniques have been developed. Classical sinusoidal pulse width modulation (SPWM) Multilevel inverter structures have been developed but still have limited better performance compared with SVPWM technique.

Providing a lower total harmonic as well as higher utilization of the dc-link voltage are the main reasons that make SVPWM technique is most widely used in inverters [1]. In SVPWM, 70.7\% of the DC link voltage can be obtained as a maximum output line voltage while only $61.2 \%$ can be obtained in sinusoidal pulse width modulation (SPWM) [2]. There are many studies offer a superior performance of SVPWM compared with SPWM [3-5]. SPWM has different algorithms to modulate the inverter which have been investigated in many literatures [6-7].

This paper presents proposed different SVPWM approaches which can be applied to the Two-Level Inverter Fed Induction Motor Drive. The objective in each modulation approach is to maximize bus utilization, reduce the switching losses, and reduce harmonic content. So the motor current, voltage, and 
torque are obtained. The main contribution of this work is providing complete comparative study between different proposed approaches and introduces a novel approach has maximum DC bus voltage utilization, with capability of loading with full load safely and lowest THD.

\section{SVPWM CONCEPT}

The using of the modulation technique's aim is to provide the output voltage and the current with less harmonic distortion. The SVPWM technique has become the most common choice to control the output voltage of three-phase voltage source inverter (VSI). The SVPWM was originally sophisticated as a vector approach to pulse width modulation (PWM) for three- phase inverter. It is a more advanced technique that provides a higher voltage to the AC motor with less harmonic distortion. The main objective of any modulation technique is to obtain a variable output with a maximum fundamental component and minimum harmonics. In this section, describes some details about two-level SVPWM based three-phase VSI [8-13]. The three-phase VSI has six power switches S1 to S6 with eight possible switch combinations. So eight possible vectors are obtained, two vectors are null vector (zero states $(8-7)$ ), and the others are voltage vector (active states (1-6)) [14].

In each motor phase winding, there must be two power switches and these two switches are complementary to each other i.e. can not be active together because there will be a short circuit on the power source. So switching function for motor phases can be defined as follow [14];

$$
S_{a}=\left\{\begin{array}{l}
1,\left(S_{1} \text { on }, S_{4} \text { off }\right) \\
0,\left(S_{1} \text { off }, S_{4} \text { on }\right)
\end{array}, S_{b}=\left\{\begin{array}{l}
1,\left(S_{3} \text { on }, S_{6} \text { off }\right) \\
0,\left(S_{3} \text { off }, S_{6} \text { on }\right)
\end{array}, S_{c}=\left\{\begin{array}{l}
1,\left(S_{5} \text { on }, S_{2} \text { off }\right) \\
0,\left(S_{5} \text { off }, S_{2} \text { on }\right)
\end{array}\right.\right.\right.
$$

In the stationary frame the space vector of the phase voltage in previous equations becomes [2];

$$
V_{K}=\frac{2}{3} V_{D C}\left(S_{a} e^{J o}+S_{b} e^{J \frac{2 \pi}{3}}+S_{C} e^{J \frac{4 \pi}{3}}\right)
$$

The voltage space vector $V_{K}$ of $\mathrm{K}=1,2, ., 6$ have equal amplitudes of $(2 / 3) \mathrm{V}_{\mathrm{DC}}$ and a phase of $(K-1)$ $p / 3$. The current level achievable by each phase by the end of the next sampling interval can be expressed.

$$
I_{S}=\frac{V_{K}-V_{D C}}{R_{1}}\left(1-e^{-t / \tau}\right)+I_{o} e^{-t / \tau}
$$

In between switching intervals, each voltage vector is constant and the stator flux linkage of one phase of the motor can be expressed as [15]:

$$
\phi_{s}=\int\left(V_{K}-I_{s} R_{1}\right) d t+\phi_{o}
$$

At steady state, the hexagon of stator flux is included within two circles as shown in Figure 1. The difference between their radii can be interpreted as the maximum deviation of stator flux.

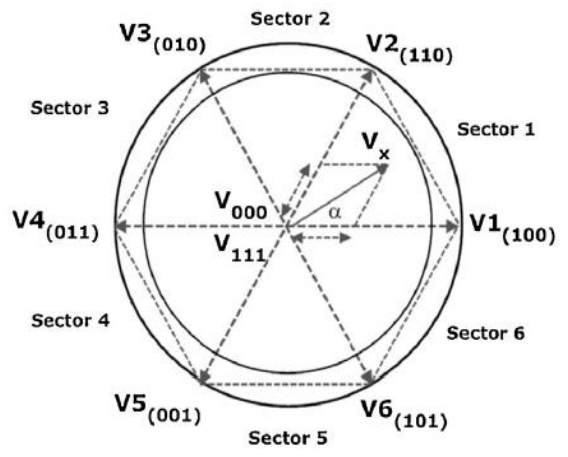

Figure 1. Space vectors hexagon of 3-phase bridge inverter [1] 
Depenbrok [16] strategy or six-step approach is aimed at minimizing the inverter switching in each supply period to the detriment of the control of the stator flux amplitude. The maximum value of the voltage due to the opening of the switch is $\mathrm{V}_{\mathrm{DC}}$ with using the work area on the outer circle respectively of the hexagon [14]. So the modulation index M can be calculated as follow [1],

$$
M=\frac{\sqrt{2} V_{L 1}}{V_{D C}}
$$

Where $V_{L 1}$ : is the RMS value of the fundamental component of motor line voltage. So the magnitude of line vector voltage varies from zero to maximum value according to $M$ (where $0 \leq M \leq 1$ )

\section{MODEL OF INDUCTION MOTORS DRIVES}

Detailed analysis for induction motor has been carried out in [17-23]. So the performance characteristics curves can easily be obtained. The equations expressed the induction model for the motor understudy can be written as follows [24];

$$
\begin{aligned}
& R_{t=} R_{1}+\frac{X_{m}^{2} R_{2} / S}{\left(R_{2} / S\right)^{2}+\left(X_{m}+X_{2}\right)^{2}} \\
& X_{t=} X_{1}+\frac{X_{m}\left(R_{2} / S\right)^{2}+X_{m} X_{2}\left(X_{m}+X_{2}\right)}{\left(R_{2} / S\right)^{2}+\left(X_{m}+X_{2}\right)^{2}} \\
& P_{c}=\left(\frac{V_{S}}{V_{r}}\right)^{2}\left(69966-144.7 \mathrm{~N}+0.1 N^{2}-0.000023 N^{3}\right)
\end{aligned}
$$

Two-level VSI fed induction motor drive may be represented by MATLAB/Simulink. The proposed model is investigated by comparing simulation result with experimental work as shown in Figure 2.

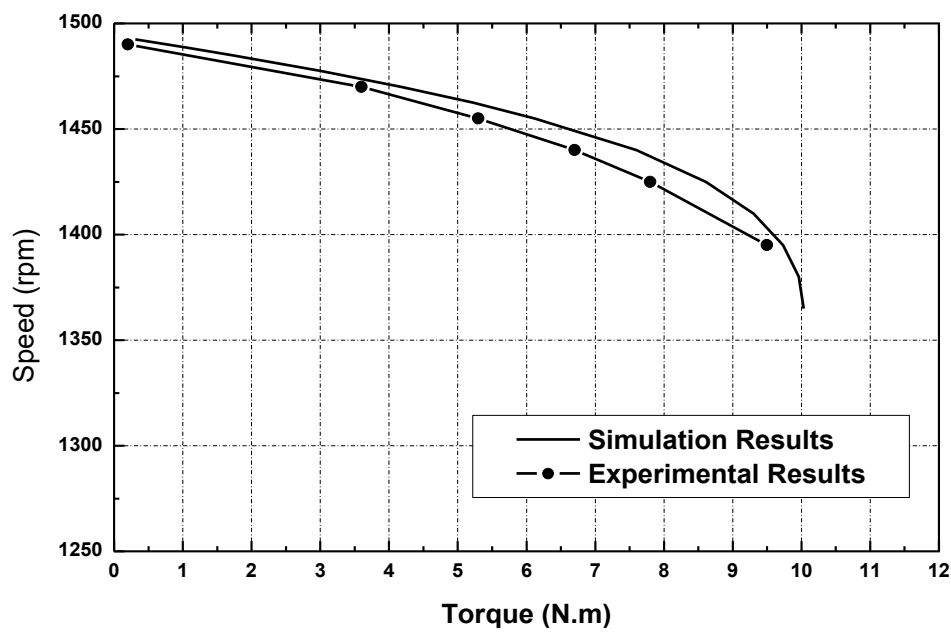

Figure 2. The variation of motor speed with load torque of two- level VSI fed induction motor drive

\section{EFFECT OF MODULATION INDEX OF SVPWM ON DRIVE PERFORMANCE}

To investigate the performance characteristics of the proposed two-level VSI Fed induction motor drive, it is assumed that the motor operating under a six-step SVPWM approach with rated voltage and current. So different DC supplies are used to achieve these assumptions with the calculation of DC bus voltage utilization, motor developed torque and total harmonic distortion of voltage and current waveforms for each case.

\subsection{Drive performance at $M=0.5$}

The waveform of phase current of the motor is shown in Figure 3(a) and Figure 3(b) shows the waveform of motor phase voltage at DC bus voltage $1170 \mathrm{~V}$. Also, Figure 4 shows the motor torque when the motor operating from a six-step SVPWM approach at $\mathrm{M}=0.5$. 


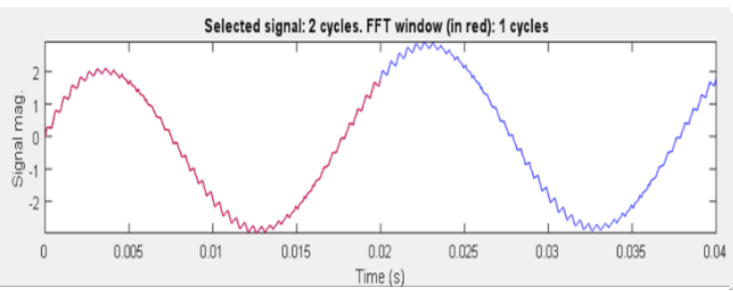

(a)

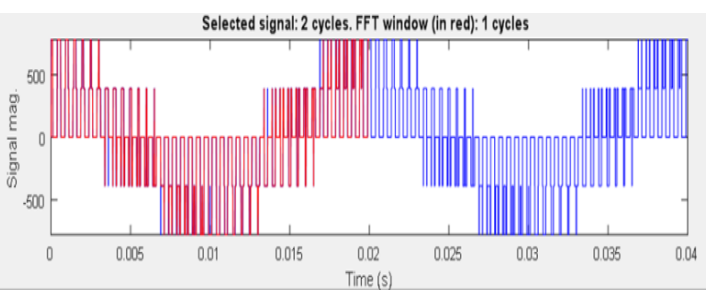

(b)

Figure 3. Motor waveforms at $\mathrm{M}=0.5$ : (a) motor phase current, (b) motor phase voltage

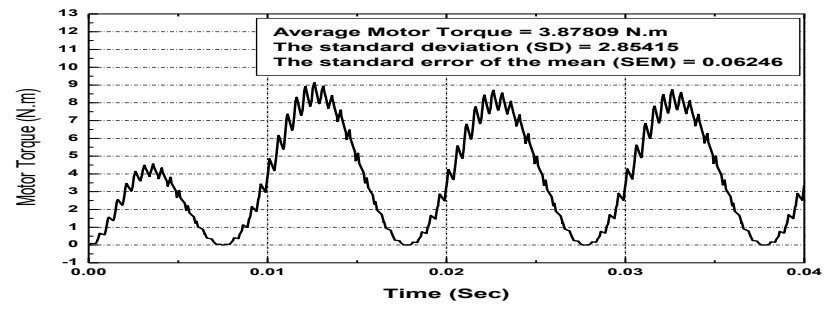

Figure 4. Motor torque with time at $\mathrm{M}=0.5$

\subsection{Drive performance at $M=0.8$}

The waveform of phase current of the motor is shown in Figure 5(a) and Figure 5(b) shows the waveform of motor phase voltage at DC bus voltage $927 \mathrm{~V}$. Also, Figure 6 shows the motor torque when the motor operating from a six-step SVPWM approach at $\mathrm{M}=0.8$.

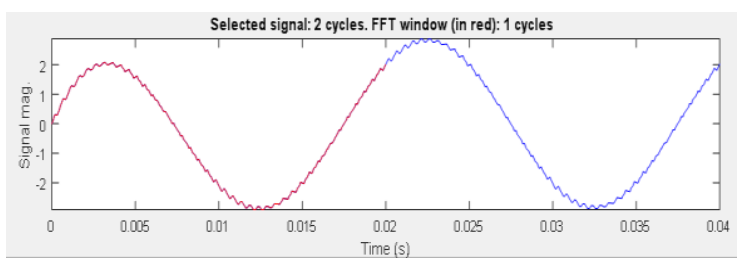

(a)

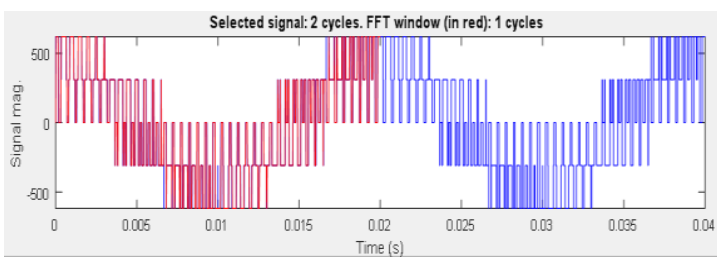

(b)

Figure 5. Motor waveforms at $\mathrm{M}=0.8$ : (a) motor phase current, (b) motor phase voltage

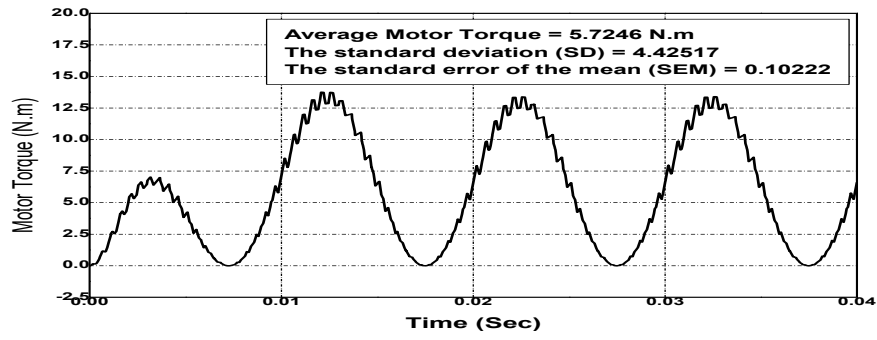

Figure 6. Motor torque with time at $\mathrm{M}=0.8$

\subsection{Drive performance at $M=1$}

The waveforms of phase current and phase voltage of the motor at DC bus voltage $830 \mathrm{~V}$ are shown in Figure 7(a) and Figure 7(b) respectively. Also, Figure 8 shows the motor torque when the motor operating from a six-step SVPWM approach at $\mathrm{M}=1$. 


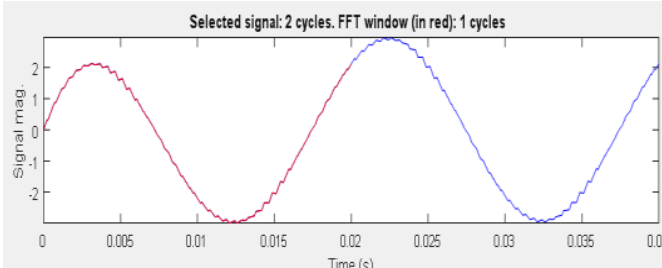

(a)

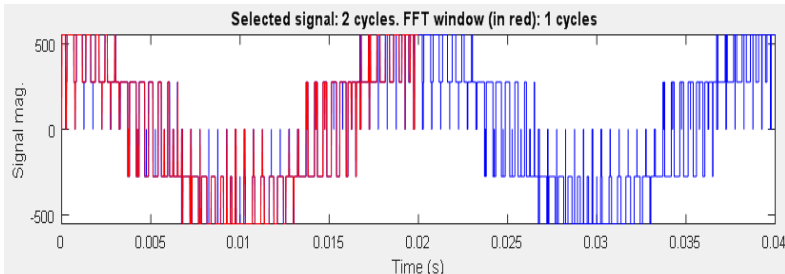

(b)

Figure 7. Motor waveforms at $\mathrm{M}=1$ : (a) motor phase current, (b) motor phase voltage

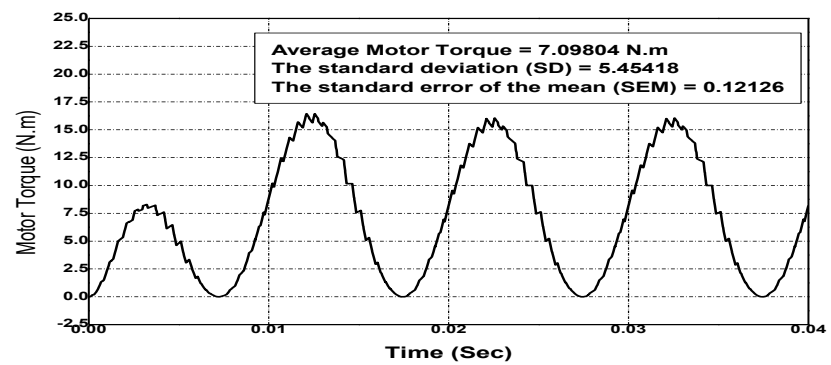

Figure 8. Motor torque with time at $\mathrm{M}=1$

From previous figures, it can be deduced that higher modulation index means better drive performance.

\section{DRIVE PERFORMANCE USING NOVAL SVPWM APPROACH}

As the previous section, the performance characteristics the proposed drive can be investigated when the motor operating under different SVPWM approach with rated voltage and current. The 24 step SVPWM approach and 48 step SVPWM approach are the proposed approaches [25]. Figure 9 shows the space vectors polygon of 3-phase bridge inverter based on 24 step SVPWM approach, Figure 10 shows the space vectors polygon of 3-phase bridge inverter based on 48 step SVPWM approach.

DC bus voltage utilization, motor developed torque and total harmonic distortion of voltage and current waveforms are calculated for each approach.

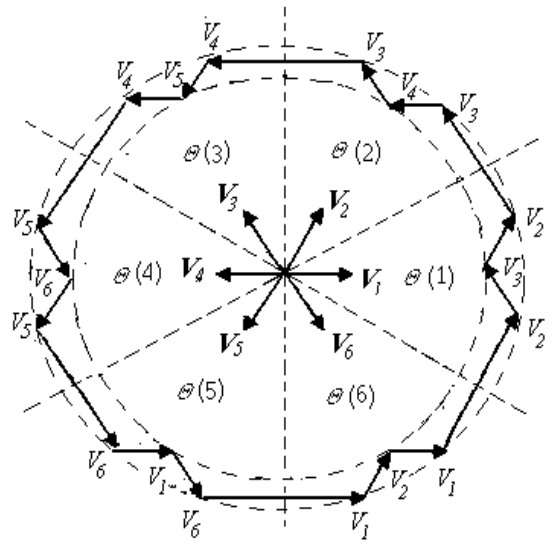

Figure 9. Space vectors polygon of 3-phas bridge

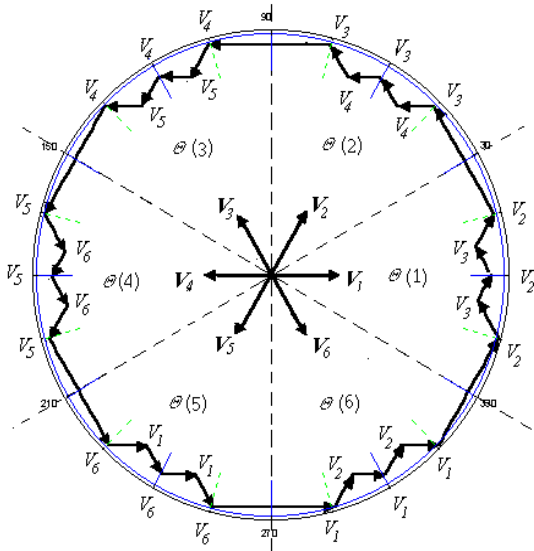

Figure 10. Space vectors polygon of 3-phas bridgeinverter based on 24 step SVPWM approach inverter based on 48 step SVPWM approach 


\subsection{Drive performance with 24 step SVPWM approach}

The waveform of phase current of the motor is shown in Figure 11(a) and Figure 11(b) shows the waveform of motor phase voltage at DC bus voltage $810 \mathrm{~V}$. Also, Figure 12 shows the motor torque when the motor operating from 24 step SVPWM approach.

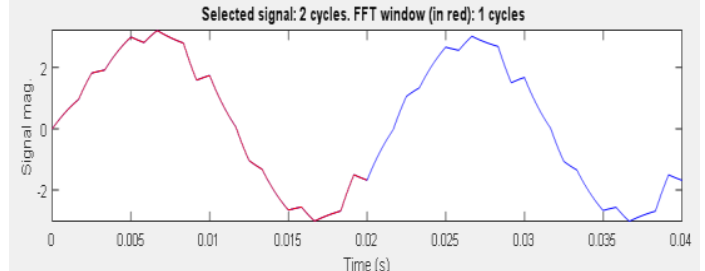

(a)

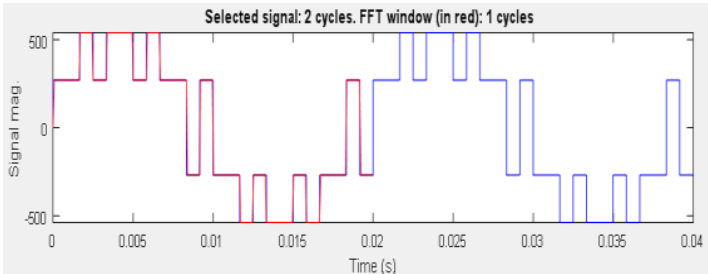

(b)

Figure 11. Motor waveforms with 24 step approach: (a) motor phase current, (b) motor phase voltage

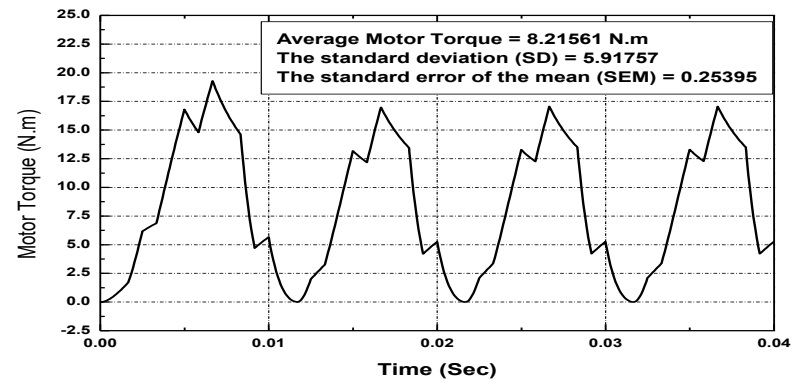

Figure 12. Motor torque with time with 24 step approach

\subsection{Drive performance with $\mathbf{4 8}$ step SVPWM approach}

The waveform of phase current of the motor is shown in Figure 13(a) and Figure 13(b) shows the waveform of motor phase voltage at DC bus voltage $808.5 \mathrm{~V}$. Also, Figure 14 shows the motor torque when the motor operating from 48 step SVPWM approach.

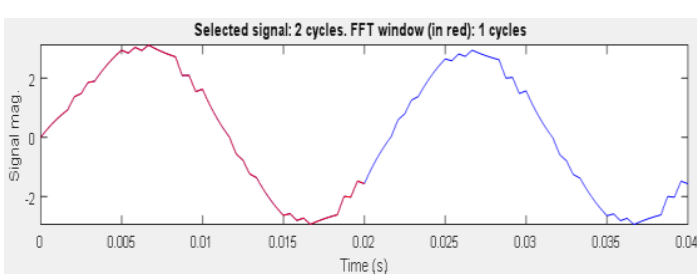

(a)

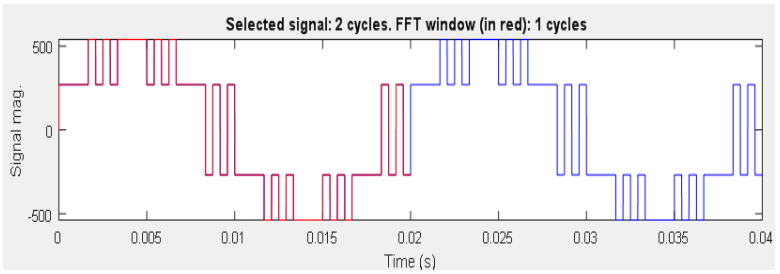

(b)

Figure 13. Motor waveforms with 48 step approach: (a) motor phase current, (b) motor phase voltage

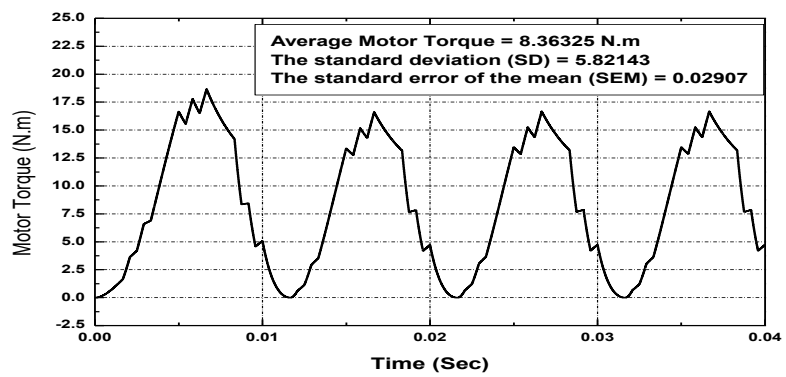

Figure 14. Motor torque with time with 48 step approach 
From previous figures, it is clear that higher steps SVPWM approaches mean better drive performance.

\section{DISCUSSION AND SIMULATION RESULTS}

The selection of modulation index and SVPWM approach affect on two-level VSI fed induction motor drive performance parameters, such as DC bus voltage utilization, motor de-rated torque (at which motor power losses will not exceed the rated power losses) and total harmonic distortion of voltage and current waveforms. Table 1 gives the comparison of results obtained at different modulation index and SVPWM approach described in sections 4 and 5. The parameters used in comparison processes are summarized below;

The DC bus voltage utilization factor $m$, can be calculated as follows;

$$
m=\frac{V_{L 1}}{V_{D C}} \times 100
$$

The De-rated Torque DT, can be calculated as follows;

$$
D T=\frac{\left.T_{a v} \text { (at rated current }\right)}{T_{r}} \times 100
$$

The standard error of the mean (average) torque (SEM) can be calculated as follows;

$$
S E M=\frac{S D}{\sqrt{n}} \times 100=\frac{100}{\sqrt{n}} \sqrt{\frac{1}{n-1} \sum_{i=1}^{n}\left(T_{i}-T_{a v}\right)^{2}}
$$

Where $\mathrm{n}$ is sample size

The Total harmonic distortion THD of phase voltage \& phase current waveforms can be shown as follows;

$$
T H D\left(V_{p h}\right)=\sqrt{\frac{V_{s 1}{ }^{2}-V_{S}^{2}}{V_{S}^{2}}}, T H D\left(I_{p h}\right)=\sqrt{\frac{I_{S 1}{ }^{2}-I_{S}{ }^{2}}{I_{S}{ }^{2}}}
$$

It is observed in Table 1 that two-level VSI Fed induction motor drive with 48 step SVPWM approach, has the best performance according to different parameters. The proposed novel approach has lower THD about $12.5 \%$ for phase current and 46.7 for phase voltage. In addition to maximum DC bus voltage utilization factor nearly $74 \%$ with the capability of loading with full load safely and resulting minimum standard error of average torque about $2.9 \%$.

Table 1. Comparison between different SVPWM approaches

\begin{tabular}{cccccc}
\hline Approach & $\begin{array}{c}\text { THD }\left(\mathrm{I}_{\mathrm{ph}}\right) \\
(\%)\end{array}$ & $\begin{array}{c}\text { THD }(\mathrm{Vph}) \\
(\%)\end{array}$ & $\begin{array}{c}m \\
(\%)\end{array}$ & $\begin{array}{c}\text { DT } \\
(\%)\end{array}$ & $\begin{array}{c}\text { SEM } \\
(\%)\end{array}$ \\
\hline 6 step $(M=0.5)$ & 18.8 & 126.2 & 35.3 & 46.4 & 6.3 \\
6 step $(M=0.8)$ & 20.6 & 77.5 & 56 & 68.5 & 10.2 \\
6 step $(M=1)$ & 20.7 & 52.5 & 70.5 & 84.9 & 12.1 \\
24 step $(M=1)$ & 13.6 & 51.3 & 72.3 & 98.3 & 25.4 \\
48 step $(M=1)$ & 12.5 & 46.7 & 74 & 100 & 2.9 \\
\hline
\end{tabular}

\section{CONCLUSION}

In this paper, the most widely used PWM scheme has been implemented and evaluated according to simulations of two- level SVPWM VSI fed induction motor drive in the Matlab/Simulink environment. The evaluation is based on rated current operation and the estimation of motor de-rated torque (at which motor power losses will not exceed the rated power losses) DC bus voltage utilization, and total harmonic distortion of voltage and current waveforms. The performance analysis of two-level SVPWM VSI fed induction motor drive with different modulation index has been presented. Also, novel SVPWM approaches have been demonstrated and have been found to be very effective approaches. The assessment process of different novel SVPWM approaches is the main contribution of this paper. As cleared in DT, m, SEM and THD values, 48 step SVPWM approach is superior in comparison to conventional SVPWM approaches. It can be concluded that 48 step SVPWM approach is worthy and beneficial towards loading capability with full load torque at rated current. 


\section{APPENDIX}

The system under study is 3-phase squirrel cage, $2 \mathrm{HP}, \mathrm{D} / \mathrm{Y}, 380$ / $660 \mathrm{~V}, 3.5$ / $2 \mathrm{~A}, 50 \mathrm{~Hz}, 4$ poles. stator reactance $X_{1}=44 \mathrm{~W}$, rotor resistance $R_{2}{ }^{\prime}=7.37 \mathrm{~W}$,

rotor reactance $X_{2}{ }^{\prime}=44 \mathrm{~W}$ and magnetizing reactance $X_{m}=377 \mathrm{~W}$.

\section{REFERENCES}

[1] Ahmed A. Mansour, "Novel SVPWM based on first order equation," Journal of Electrical Systems and Information Technology, vol. 2, no. 2, pp. 197-206, 2015

[2] M. Ranjit, "Space Vector Pulse Width Modulation Based Indirect Vector Control of Induction Motor Drive," Journal of Electrical \& Electronic Systems, vol. 1, issue 4, pp. 1-6, Sept. 2015

[3] A. El-sanabary, A. E. Kalas, O. M. Elbaksawi and K. El-serafy, "Comparative Study Between PSPWM and SVPWM Techniques Based on MLI for Induction Motor Drive," Journal of Electrical Engineering, vol, issue, pp. 1-8, Dec. 2017

[4] K. Vinoth Kumar, Prawin Angel Michael, Joseph P. John and Dr. S. Suresh Kumar, "Simulation and Comparison of SPWM and SVPWM Control for Three Phase Inverter," ARPN Journal of Engineering and Applied Sciences, vol. 5, no. 7, pp. 61-74, 2010

[5] H. Doraya, R. Parmar, B. Kumar, and M. C. sharma, "Performance Comparison between PWM Based Inverter and SVPWM Based Inverter," International Journal of Advanced Research in Electrical, Electronics and Instrumentation Engineering, vol. 3, issue 10, pp. 12621-12625, 2014

[6] W. F. Zhang and Y. H. Yu, "Comparison of Three SVPWM Strategies," Journal of Electronics Science and Technology of china, vol. 5, no. 3, pp. 283-287, 2007

[7] M. Nayeemuddin, T. B. Reddyb, and M. V. Kumara, "Space Vector based Random PWM Algorithms for Acoustic Noise and Harmonics Reduction for Voltage Source Inverter Fed AC Drive," Energy Procedia, vol. 117, pp. 353-360, 2017

[8] S. Manivannan, S. Veerakumar, P. Karuppusamy, and A. Nandhakumar, "Performance Analysis of Two-Level Space Vector Pulse Width Modulated Three Phase Voltage Source Inverters In All Possible Switching Sequences," International Journal of Innovative Research in Electrical, Electronics, Instrumentation and Control Engineering, vol. 2, issue 9, pp. 1959-1976, Sept. 2014

[9] M. Botkewar, K. Sawalakhe, and N. Wanjari, "Performance Analysis of Three Phase Induction Motor Drive Using SVPWM Switching Techniques: Design Approach," International Journal of Innovative Research and Development, vol. 5, no. 7, 2016.

[10] L. Tan, B. Wu, V. Sood, D. Xu, M. Narimani, Z. Cheng, et al., "A Simplified Space Vector Modulation for FourLevel Nested Neutral-Point Clamped Inverters with Complete Control of Flying-Capacitor Voltages," IEEE Transactions on Power Electronics, vol. 33, pp. 1997-2006, 2018.

[11] Y. Deng, Y. Wang, K. H. Teo, M. Saeedifard, and R. G. Harley, "Optimized Control of the Modular Multilevel Converter Based on Space Vector Modulation," IEEE Transactions on Power Electronics, vol. 33, pp. $5697-$ $5711,2018$.

[12] K. Pratheesh, G. Jagadanand, and R. Ramchand, "A Generalized Switch Matrix Based Space Vector Modulation Technique Using the Nearest Level Modulation Concept for Neutral-Point-Clamped Multilevel Inverters," IEEE Transactions on Industrial Electronics, vol. 65, pp. 4542-4552, 2018.

[13] M. Aleenejad, H. Mahmoudi, S. Jafarishiadeh, and R. Ahmadi, "Fault-Tolerant Space Vector Modulation for Modular Multilevel Converters with Bypassed Faulty Submodules," IEEE Transactions on Industrial Electronics, vol. 66 , pp. 2463-2473, 2019.

[14] A. Giyantara and M. Rameli, "Comparison between SVPWM Two Level in Internal and External Circle of Hexagon," International Conference on Engineering, Science and Nanotechnology (ICESNANO 2016), August 35, 2016, Solo, Indonesia. AIP Conference Proceedings 1788, 030007 (2017)

[15] S. Karpe, S. A. Deokar, and A. M. Dixit, "Switching losses minimization by using direct torque control of induction motor," Journal of Electrical Systems and Information Technology, vol. 4, pp. 225-242, 2017

[16] M.Depenbrock, "Direct Self-Controlled DSC of Inverter fed Induction Machines" IEEE Tran. Power Electron, Vol. 3, pp. 420-429. Oct. 1988.

[17] Mohamed A. Enany, "Energy Saving of AC Voltage Controller Fed Induction Motor Drives Using Matlab /Simulink," International Journal of Electrical Engineering, IJEE, Vol. 6, No. 2, pp. 123-136, 2013.

[18] Mohamed A. Enany, "Effects of Three Phase AC Voltage Controller on Performance Characteristic of Induction Motor," International Review of Automatic Control, IREACO., Vol. 6, No. 2, pp.121-126, March. 2013.

[19] Sundareswaran, K.; Shyam, H.N.; Abraham, S.; Varakumar, G.; Kaul, S.; Sheeba, R.," A Genetic Algorithm Based Approach towards Induction motor starting with minimum torque pulsation," Proc. ICIIS, 2008, pp. $1-6$.

[20] Yetgin AG, "Effects of induction motor end ring faults on motor performance. Experimental results," Engineering Failure Analysis. Vol. 96, pp. 374-83, 2019.

[21] A A Ansari, D M Deshpande "Mathematical Model of Asynchronous Machine in MATLAB Simulink" International Journal of Engineering Science and Technology, Vol. 2, No. 5, 2010.

[22] H. C. Stanley, “An Analysis of the Induction Motor," AIEE Transactions, Vol. 57 (Supplement), pp. 751-755, 1938. 
[23] Burak Ozpineci, L.M. Tolbertr, "Simulink Implementation of Induction Machine Model-A modular approach," IEEE rans.2003.

[24] Mohamed A. Enany, "Effects of Three Phase AC Voltage Controller on Induction Motor Performance Using ANFIS," International Journal of Electrical Engineering, Vol. 20, No. 5, pp. 225-230, 2013.

[25] Mohamed A. Enany, H. Elshewy and F. Abdel-kader, "Dynamic Operation of Synchronous Motor Using DTC Technique Instead of Damper Winding," 15th International Middle East Power Systems conference, MEPCON 2012, DEC. 23- 25 2012, Alexandria University, Egypt.

\section{BIOGRAPHIES OF AUTHORS}

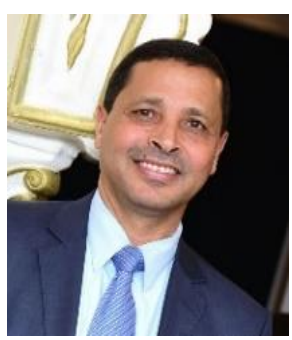

E. E. El-Kholy was born in Menoufia, Egypt in 1963. He received his BSc, MSc and PhD degrees in electrical engineering from the Faculty of Engineering, Menoufia University in 1986, 1992 and 1996 respectively. He is the Dean of Faculty of Engineering, Menoufia University. His main field of interest includes Power Electronics, AC/DC drives control techniques, Active Rectifiers, Active Filters, Microgrids and Renewable Energy. His interest also extended to RealTime control using DSP, Fuzzy application in Power Electronics.

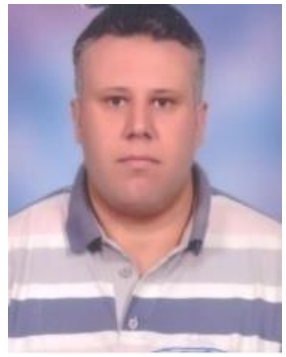

Mohamed A. Enany was born on 1st January 1979. He received all B.Sc., M.Sc. and PhD degrees in electrical power and machines engineering from Engineering College, Zagazig University, Egypt on 2000, 2005 and 2009, respectively. He has many international publications in the area of Electrical Machines, Renewable Energy, soft computing techniques and Electrical Drives. He is currently an Associate Professor in electrical power and machines engineering from Engineering College, Zagazig University, Egypt.

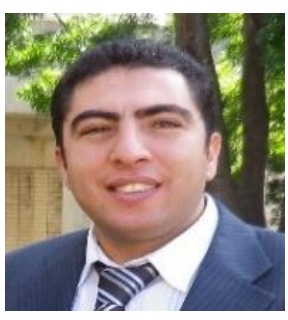

Ahmed Fathi Abdou received his B.Sc. and M.Sc. Eng. degrees from Faculty of Engineering, Menoufia University, Egypt, and $\mathrm{PhD}$ degree in 2013 from the University of New South Wales, at the Australian Defence Force Academy. His research interests include power electronics, renewable energy, smart grids, distributed generation, electrical machines, voltage stability, FACTS devices and control applications. He is a regular reviewer for many of international journals.

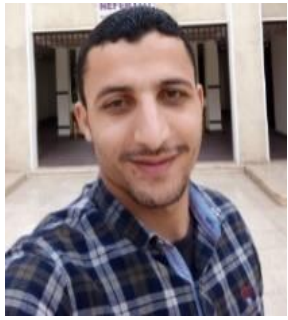

Mahmoud Eid Mohamed was born in Belbis, Egypt in 1991. He received his B.Sc. Eng. degree from Faculty of Engineering, Zagazig University, Egypt in 2015. Currently, he is a Teaching Assistant at the Faculty of Engineering, Zagazig University, Egypt. 